Економічні науки: збірник наукових праиь Луиького національного технічного університету. - Серія "Регіональна економіка". - Випуск 15 (59). - Редкол.: відп. ред. д.е.н., професор Л.Л. Ковальська. - Луиьк: ІВВ Луиького НТУ, 2018. - 292 с.

УДК 67.404 .2

Ковальська Л.Л., д.е.н., професор, завідувач кафедри підприємництва, торгівлі та біржової діяльності

Луцький національний технічний університет Аухімік O.В.

Луцький національний технічний університет

\title{
МЕТОДИКА АНАЛІЗУ ТА ОЦІНКИ КОНКУРЕНТОСПРОМОЖНОСТІ РЕСУРСНОГО ПОТЕНЦІАЛУ: МІКРО- ТА МЕЗОАСПЕКТИ
}

У статті подано авторське бачення методики аналізу та оцінки конкурентоспроможності ресурсного потенціалу підприємства. Запропоновано етапність оцінки конкурентоспроможності ресурсного потенціалу: визначення мети та завдань оцінки конкурентоспроможності ресурсного потенціалу; вибір методів оцінки конкурентоспроможності ресурсного потенціалу; комплексна оцінка конкурентоспроможності ресурсного потенціалу. Оцінку конкурентоспроможності ресурсного потенціалу підприємства запропоновано оцінювати за трьома методами: критеріальним, індексним та експертним.

Ключові слова: ресурси, потенціал, конкурентоспроможність, конкурентоспроможність ресурсного потенціалу, підприємство, мікрорівень, мезорівень, метод. 

університету. - Серія "Регіональна економіка". - Випуск 15 (59). - Редкол.: відп. ред. д.е.н., професор Л.Л. Ковальська. - Луцьк: ІВВ Луцького НТУ, 2018. - 292 с.

\section{Kovalska L., Auchim O. METHOD OF ANALYSIS AND ESTIMATION OF COMPETITIVENESS OF RESOURCE POTENTIAL: MICRO- AND MEASURES}

The author's vision of the method of analysis and evaluation of the competitiveness of the resource potential of the enterprise is presented in the article. The stage of the estimation of the competitiveness of resource potential is proposed: definition of the goal and objectives of the assessment of the competitiveness of the resource potential; selection of methods for assessing the competitiveness of resource potential; integrated assessment of the competitiveness of resource potential. The assessment of the competitiveness of the resource potential of the enterprise is proposed to be evaluated in three ways: crite- ral, index and expert.

Key words: resources, potential, competitiveness, resource potential competitiveness, enterprise, micro level, mezorite, method.

Ковальская Л.Л., Аухимик А.В.

\section{МЕТОДИКА АНАЛИЗА И ОЦЕНКИ КОНКУРЕНТОСПОСОБНОСТИ РЕСУРСНОГО ПОТЕНЦИАЛА: МИКРО- И МЕЗОАСПЕКТЫ}

В статье представлено авторское видение методики анализа и оценки конкурентоспособности ресурсного потенциала предприятия. Предложено этапность оценки конкурентоспособности ресурсного потенциала: определение целей и задач оценки конкурентоспособности ресурсного потенциала; выбор методов оценки конкурентоспособности ресурсного потенциала; комплексная оценка конкурентоспособности ресурсного потенциала. Оценку конкурентоспособности ресурсного потенциала предприятия предложено оценивать по трем методам: критериальным, индексным и экспертным.

Ключевые слова: ресурсы, потенциал, конкурентоспособность, конкурентоспособность ресурсного потенциала, предприятие, микроуровень, мезоуровень, метод.

\section{Постановка проблеми у загальному вигляді та ії} зв'язок з важливими науковими і практичними завданнями. В умовах посилення конкуренції на ринку товарів та послуг вимагає від підприємства забезпечення високого рівня конкурентоспроможності, ефективного використання конкурентних переваг та ресурсного потенціалу. Прийняття 

університету. - Серія "Регіональна економіка". - Випуск 15 (59). - Редкол.: відп. ред. д.е.н., професор Л.Л. Ковальська. - Луиьк: ІВВ Луиького НТУ, 2018. - 292 с.

виважених управлінських рішень щодо підвищення конкурентоспроможності підприємства та його ресурсного потенціалу потребують детального аналізу та оцінки конкурентних переваг підприємства, його можливостей утримувати конкурентні позиції. Важливим для формування та підвищення конкурентоспроможності $\epsilon$ ідентифікація його наявного стану через розробку методичного підходу до аналізу та оцінки конкурентоспроможності ресурсного потенціалу підприємства.

Аналіз останніх досліджень, у яких започатковано вирішення проблеми. Питаннями, що стосуються дослідження конкурентоспроможності ресурсного потенціалу підприємства, аналізу та оцінки його рівня займалися такі науковці як Ковальська Л.Л. [5], Олексюк О.I. [4], Рєпіна I.М. [4], Салавеліс Д.С. [3], Севастьянов Р.В. [1], Федонін О.С. [4] та інші. Однак, незважаючи на значні напрацювання в цій сфері, i досі залишаються невирішеними та дискусійними питання щодо єдиної комплексної методики аналізу та оцінки конкурентоспроможності ресурсного потенціалу.

Цілі статті. Тому, метою дослідження $є$ розробка методики аналізу та оцінки конкурентоспроможності ресурсного потенціалу на мікро- та мезорівнях.

Виклад основного матеріалу дослідження 3 обгрунтуванням отриманих наукових результатів. Оскільки аналіз та оцінка конкурентоспроможності ресурсного потенціалу на мікро- та мезорівнях є трудомістким процесом, який вимагає використання сукупності методів, показників та критеріїв оцінки, то його доцільно представити у наступному вигляді (рис.1). 
Економічні науки: збірник наукових праиь Луиького національного технічного університету. - Серія "Регіональна економіка". - Випуск 15 (59). - Редкол.: відп. ред. д.е.н., професор Л.Л. Ковальська. - Луиьк: ІВВ Луиького НТУ, 2018. - 292 с.

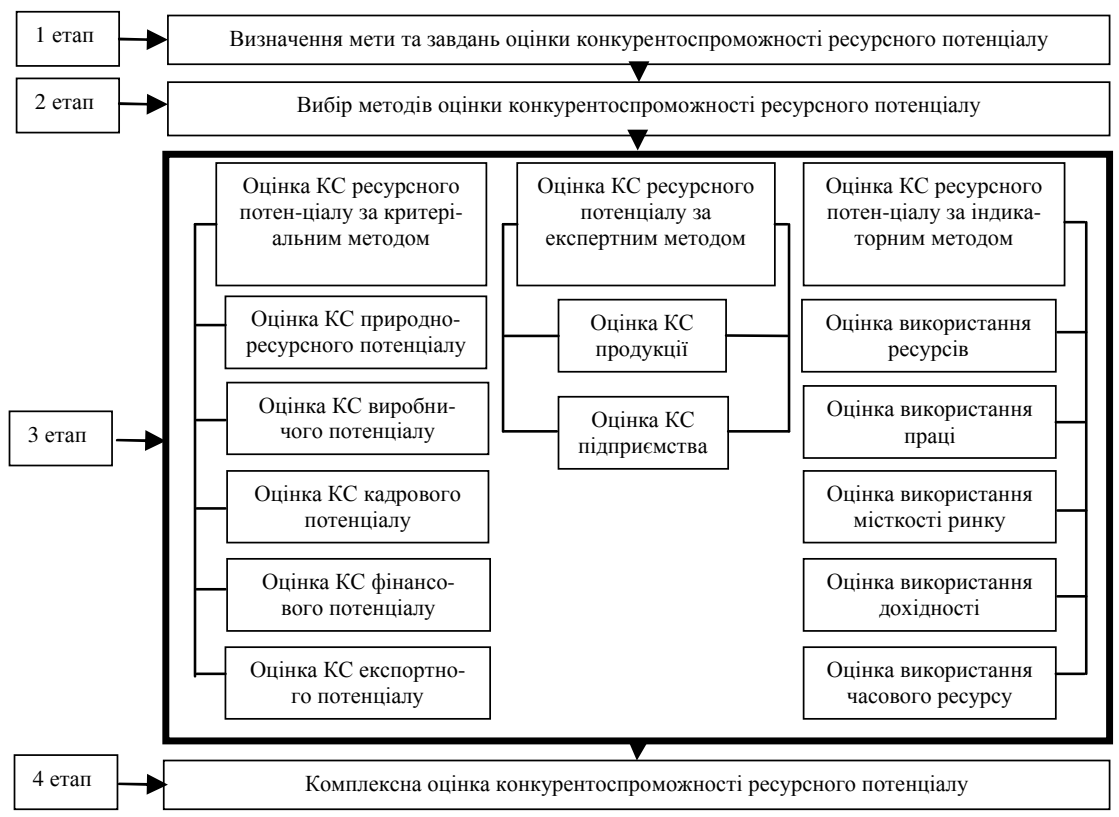

Рис. 1. Методика аналізу та оцінки ресурсного потенціалу на мікро- та мезорівнях

Розглянемо зміст цих етапів. На першому етапі обирається мета оцінки, яка полягає в комплексній оцінці конкурентоспроможності ресурсного потенціалу. Відповідно до поставленої мети основним завданням $\epsilon$ оцінка конкурентоспроможності ресурсного потенціалу за сукупністю методів. На другому етапі для оцінки конкурентоспроможності ресурсного потенціалу будуть використані: критеріальний метод, що полягає у порівнянні фактичних даних показників із визначеними критеріями - нормативними або середньогалузевими значеннями; індикаторний метод, що представляє собою порівняння значень індикаторів досліджуваного підприємства із значеннями індикаторів підприємства-конкурента; експертний метод оцінює конкурентоспроможність ресурсного потенціалу на основі експертно встановлених вагових коефіцієнтів та балів. 
Економічні науки: збірник наукових праиь Луиького національного технічного університету. - Серія "Регіональна економіка". - Випуск 15 (59). - Редкол.: відп. ред. д.е.н., професор Л.Л. Ковальська. - Луиьк: ІВВ Луиького НТУ, 2018. - 292 с.

\section{Визначення рівня конкурентоспроможності ресурсного} потенціалу за трьома методами дасть змогу реально та ефективно оцінити ресурсний потенціал на мікро- та мезорівнях, мінімізувати недоліки одного методу, компенсуючи їх перевагами інших, а також зменшити можливий діапазон похибки отриманих результатів.

Далі слід визначити напрями та критерії оцінки конкурентоспроможності ресурсного потенціалу за критеріальним методом. До напрямів за вибраним методом відносяться: оцінка конкурентоспроможності фінансового потенціалу, оцінка конкурентоспроможності кадрового потенціалу, оцінка конкурентоспроможності виробничого потенціалу, оцінка конкурентоспроможності природноресурсного потенціалу, оцінка конкурентоспроможності експортного потенціалу. Критеріями виступають середньогалузеві значення або нормативні показники (3-й етап). Після чого проводиться вибір системи показників аналізу та оцінки конкурентоспроможності ресурсного потенціалу [1].

Згодом, здійснюється загальна оцінка ресурсного потенціалу за критеріальним методом (табл. 2) [2, 3].

Таблиця 2

Формули для загальної оцінки ресурсного потенціалу за

\begin{tabular}{|c|c|c|}
\hline \multicolumn{3}{|c|}{ критеріальним методом $[2,3]$} \\
\hline Назва формули & $\begin{array}{c}\text { Формула } \\
\text { розрахунку }\end{array}$ & Позначення \\
\hline 1 & 2 & 3 \\
\hline 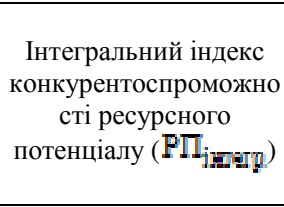 & $\mathrm{PI}_{\text {imap }}=$ & $\begin{array}{l}\mathbf{k}_{\mathbf{i}} \text { - ваговий коефіціснт групи показ- } \\
\text { ників оцінки конкурентоспроможності } \\
\text { складових ресурсного потенціалу; } \\
\mathbf{P}_{\mathbf{i}}-\text { iнтегральний індекс конкуренто- } \\
\text { спроможності складових ресурсного } \\
\text { потенціалу. }\end{array}$ \\
\hline $\begin{array}{c}\text { Оціночний коефіцієнт } \\
\text { показників оцінки } \\
\text { конкурентоспроможно } \\
\text { сті складових } \\
\text { ресурсного потенціалу } \\
\left(k_{j}\right)\end{array}$ & $k_{j}=\frac{1}{q_{j}} s h_{j}$ & $\begin{array}{l}\text { gi - нормативне або середньогалузеве } \\
\text { значення відповідного показника; } \\
\text { h }_{\mathbf{i}} \text {-ваговий коефіцієнт відповідного } \\
\text { показника. }\end{array}$ \\
\hline
\end{tabular}


Економічні науки: збірник наукових праџь Луцького національного технічного університету. - Серія "Регіональна економіка". - Випуск 15 (59). - Редкол.: відп. ред. д.е.н., професор Л.Л. Ковальська. - Луцьк: ІВВ Луцького НТУ, 2018. - 292 с.

Продовження таблиці 2

\begin{tabular}{|c|c|c|}
\hline 1 & 2 & 3 \\
\hline $\begin{array}{c}\text { Інтегральний індекс } \\
\text { конкурентоспроможно } \\
\text { сті складових } \\
\text { ресурсного потенціалу } \\
\left(\mathbb{P}_{\mathfrak{i}}\right)\end{array}$ & $\mathrm{P}_{i}=\frac{\sum_{i=1} \Pi_{j} * k_{j}}{m}$ & $\begin{array}{l}\mathrm{m}-\text { кількість показників оцінки } \\
\text { складових ресурсного потенціалу; } \\
\mathbb{\Pi}_{j}-\text { показники оцінки конкурен- } \\
\text { тоспроможності складових ресурсного } \\
\text { потенціалу; } \\
b_{j}-\text { оціночні коефіцієнти показників } \\
\text { оцінки конкурентоспроможності скла- } \\
\text { дових ресурсного потенціалу. }\end{array}$ \\
\hline
\end{tabular}

Інтегральні індекси складових ресурсного потенціалу дають змогу оцінити ефективність використання природноресурсного, виробничого, кадрового, фінансового та експортного потенціалів окремо. Рівень ефективності їх використання можна визначити за тією ж таблицею, що й інтегральний індекс ефективності використання ресурсного потенціалу в таблиці 3 .

Інтегральний індекс конкурентоспроможності ресурсного потенціалу дасть змогу оцінити стан та ефективність управління ресурсним потенціалом на мікро- та мезорівнях в цілому.

Оцінити конкурентоспроможність ресурсного потенціалу на мікро- та мезорівнях за допомогою інтегрального показника можна за допомогою таблиці 3.

Таблиця 3

Оцінка інтегрального показника конкурентоспроможності ресурсного потенціалу на мікро- та мезорівнях

\begin{tabular}{|c|c|}
\hline Значення & Оцінка \\
\hline $0<\mathrm{PI}_{\text {jwerp }}<0,33$ & Ресурсний потенціал не $є$ конкурентоспроможним \\
\hline $0,33<\mathbb{P I}_{\text {jz⿻rp }}<0,67$ & $\begin{array}{l}\text { Середній рівень конкурентоспроможності } \\
\text { ресурсного потенціалу }\end{array}$ \\
\hline $0,67<\mathbf{P I}_{\text {jwerp }}<1$ & $\begin{array}{c}\text { Високий рівень конкурентоспроможності ресурсного } \\
\text { потенціалу }\end{array}$ \\
\hline $\mathrm{PI}_{\text {hamp }}>1$ & $\begin{array}{c}\text { Дуже високий рівень конкурентоспроможності } \\
\text { ресурсного потенціалу }\end{array}$ \\
\hline
\end{tabular}

За індикаторним методом конкурентоспроможність ресурсного потенціалу розраховується за індикаторами, які наведені в таблиці 4 (3 етап). 
Економічні науки: збірник наукових праиь Луиького національного технічного університету. - Серія "Регіональна економіка". - Випуск 15 (59). - Редкол.: відп. ред. д.е.н., професор Л.Л. Ковальська. - Луцьк: ІВВ Луиького НТУ, 2018. - 292 с.

Таблиця 4 Індикатори оцінки конкурентоспроможності потенціалу [4, 5]

\begin{tabular}{|c|c|c|c|}
\hline $\begin{array}{c}\text { Назва } \\
\text { індикатора }\end{array}$ & Формула розрахунку & Позначення & Напрямок \\
\hline 1 & 2 & 3 & 4 \\
\hline $\begin{array}{c}\text { Індикатор } \\
\text { використання } \\
\text { ресурсів (КР) }\end{array}$ & $\mathrm{FP}=\frac{4 \Pi}{\mathrm{BEC}}: \frac{\mathrm{PA}}{\mathrm{PB}}$ & $\begin{array}{l}\text { ЧП - чистий прибуток } \\
\text { підприємства; } \\
\text { ВБС - відрахування до } \\
\text { бюджету та соціальних } \\
\text { фондів; } \\
\text { РА - ресурси, авансовані } \\
\text { підприємством; } \\
\text { Р3 - ресурси, застосовані } \\
\text { підприємством. }\end{array}$ & $\rightarrow \max$ \\
\hline $\begin{array}{c}\text { Індикатор } \\
\text { використання } \\
\text { праці }(K \Pi) \\
\end{array}$ & $\mathrm{KI}=\frac{4 \Pi}{\mathrm{BPM}}$ & $\begin{array}{l}\text { ВРМ - вартість робочих } \\
\text { місць підприємства. }\end{array}$ & $\rightarrow \max$ \\
\hline $\begin{array}{c}\text { Індикатор } \\
\text { місткості ринку } \\
(K \mathrm{M})\end{array}$ & $\mathrm{KM}=\frac{\mathrm{BM}}{\mathrm{MMP}}$ & $\begin{array}{l}\text { ВП - валовий прибуток } \\
\text { підприємства; } \\
\text { ПМР - прибуткова місткість } \\
\text { ринку даного товару. }\end{array}$ & $\rightarrow \max$ \\
\hline $\begin{array}{c}\text { Індикатор } \\
\text { дохідності (KД) }\end{array}$ & $\mathrm{K}, I=\frac{\boxplus Д \Pi}{\mathrm{B} \Omega \Gamma}$ & $\begin{array}{l}\text { ВДП - валовий доход } \\
\text { підприємства у розрахунку } \\
\text { на одного робітника, } \\
\text { включаючи власників } \\
\text { підприємства; } \\
\text { ВДГ - аналогічний доход, } \\
\text { який отримується в } \\
\text { комерційній сфері (галузі) } \\
\text { діяльності в цілому в } \\
\text { економіці країни. }\end{array}$ & $\rightarrow \max$ \\
\hline $\begin{array}{c}\text { Індикатор } \\
\text { використання } \\
\text { часового } \\
\text { ресурсу }(K Ч)\end{array}$ & $\frac{4 B A}{92 B M}$ & $\begin{array}{l}\text { ЧВД - час, за який } \\
\text { вимірюєтья отриманий } \\
\text { валовий дохід підприємства; } \\
\text { Ч2ВД - час, який } \\
\text { необхідний для збільшення } \\
\text { цього показника вдвічі. }\end{array}$ & $\rightarrow \max$ \\
\hline
\end{tabular}

Наведені показники зіставляються 3 аналогічними нормативними або фактичними показниками конкурентів, що дає змогу оцінити рівень конкурентоспроможності потенціалу на мікро- та мезорівнях.

Останній етап методики полягає в проведенні комплексної оцінки конкурентоспроможності ресурсного потенціалу на мікро- та мезорівнях. Її можна розрахувати за методами середнього арифметичного, середнього гармонічного, 
Економічні науки: збірник наукових праџь Луцького національного технічного університету. - Серія "Регіональна економіка". - Випуск 15 (59). - Редкол.: відп. ред. д.е.н., професор Л.Л. Ковальська. - Луиьк: ІВВ Луиького НТУ, 2018. - 292 с.

середнього геометричного, середнього квадратичного від значень показників конкурентоспроможності за трьома методами, а після цього подати узагальнену середню отриманих середніх.

Висновки. Наведені методи оцінки дозволять комплексно оцінити рівень конкурентоспроможності ресурсного потенціалу на мікро- та мезорівнях та на цій основі розробити механізм забезпечення конкурентоспроможності ресурсного потенціалу.

1. Севастьянов Р.В. Конкурентоспроможність потенціалу як необхідна умова розвитку підприємств / Р.В. Севастьянов, О.А. Попов // Економічний вісник Запорізької державної інженерної академії.-2017. -№2(08).-С. 25-30.

2. Воронкова А.Э. Стратегическое управление конкурентоспособным потенциалом предприятия: диагностика и организация / А.Э. Воронкова. Луганск :И-воВосточноукраинского национального университета. $-2000 .-310$ с.

3. Салавеліс Д.С. Удосконалення оцінки конкурентоспроможності потенціалу підприємства / Д.С. Салавеліс // Вісник соціально-економічних досліджень. - Одеса: Одеський національний економічний університет. - 2015. - № 57(2). - C. 156 - 161.

4. Федонін О.С., Рєпіна І.М., Олексюк О.І. Потенціал підприємства: формування та оцінка: Навчальний посібник. - К.: КНЕУ, 2004. - 316 с.

5. Ковальська Л.Л. Управління потенціалом підприємства: Навчальний посібник. / Герасимчук 3.В., Ковальська Л.Л. // - Луцьк,: «Волинські старожитності», 2012. - 336 с. 